\section{Bra om befolkningsutviklingen}

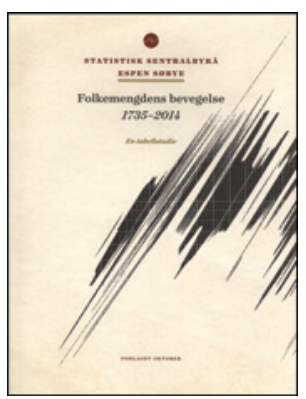

Espen Søbye

Folkemengdens bevegelse 1735-2014

En tabellstudie. 333 s, tab, ill. Oslo: Forlaget

Oktober, 2014. Pris NOK 449

ISBN 978-82-495-1359-8

Espen Søbyes bok har undertittelen En tabellstudie. Det er Statistisk sentralbyrås store tabell over befolkningsutviklingen i Norge fra 1735, publisert på forskjellige tidspunkter fra første gang i 1914, som han portretterer. Boken gir «kjøtt på beina» til tabellens tørre tall. Gjennom bakgrunnsstoffet gjør teksten det historiebildet som tallene gir, synlig og levende for leseren. Supplerende data trekkes inn, og teksten inspirerer til å lete etter flere opplysninger på egen hånd, f.eks. på Statistisk Sentralbyrås nettsider www.ssb.no, en gullgruve for alle som er interessert i det norske folks liv og levnet.

Forfatteren forteller historien om hvordan registreringen er blitt til, kommenterer ulike utgaver av tabellen opp gjennom årene, og diskuterer blant annet problemene som oppstår i perioder når det blir uro i registreringen, slik som under Den annen verdenskrig. Han forteller også om hvordan f.eks. en interpolering når et bakgrunnstall mangler, kan svekke tabellens verdi for den som leter etter interessante mønstre eller vil teste hypoteser.

Espen Søbye (f. 1954) har bakgrunn som filosof, men har arbeidet mange år i Statistisk sentralbyrå. Han er også kjent som litteraturkritiker, biograf og sakprosaforfatter. Denne kompetansen har han tatt med seg inn $i$ arbeidet med denne boken, som er spennende lesning fra først til sist. Illustrasjonene er gode. Foruten tabeller og diagrammer finner vi meget godt reprodusert bildemateriale og faksimiler.

Har boken spesiell interesse for leger og medisinstudenter? Over de to sidene 290-291 står et stort, i og for seg velkjent, diagram, her oppdatert til 2014. Basert på tabellen forfatteren skriver om, viser det fødsler, dødsfall, innvandring og utvandring siden 1735. Kurvene stiger og synker i et interessant mønster. Vi ser at bare i løpet av de siste 20 årene er det store forandringer. Diagrammet har vært - og er - et ypperlig utgangspunkt for undervisning i samfunnsmedisin og medisinsk historie. Det er iøynefallende hvordan dagens eldre pasienter ofte er født og oppvokst $i$ en tid som var ganske annerledes enn nå. En nyutdannet lege skal kanskje være $i$ arbeid i 50 år fremover. Befolkningsutviklingen stopper ikke. Hva vil skje? Søbyes bok er et håndfast argument for å få mer historisk og samfunnvitenskapelig kunnskap inn i medisinstudiet.

Ankepunkter? Innholdsmessig kunne det vært enda mer om utviklingen de siste par generasjonene. Både internasjonalt og her i landet har det vært stor interesse for sosialhistorie i denne perioden, slik at det hadde vært mulig å benytte enda bredere penn $\mathrm{i}$ beskrivelsen av tallenes kontekst. Historiebildet kunne vært mer vidvinklet. Det kunne også vært en fyldigere innholdsfortegnelse og et sakregister, slik at det hadde blitt lettere å finne frem.

En av befolkningsstatistikkens fedre i Norge, Anders Nicolai Kiær (1838-1919), sa i 1871: «Den der bruger tallene uden at ha gjort sig kjent med livet, der ligger bagom, utsætter sig læt for at drage falske slutninger.» Søbyes bok er en god hjelp til å unngå falske slutninger.

Øivind Larsen

Professor emeritus, Institutt for helse og samfunn Universitetet i Oslo

\section{Dansk bok om miljø- og arbeidsmedisin i ny utgave}

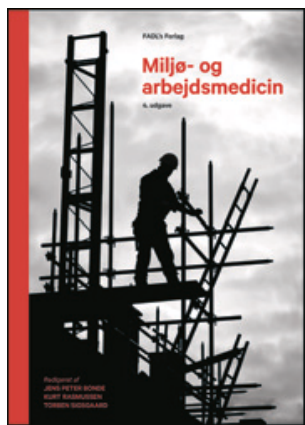

Jens Peter Bonde, Kurt Rasmussen,

Torben Sigsgaard, red.

Miljø- og arbejdsmedicin

4. utg. 354 s, tab, ill. København: FADL's

forlag, 2015. Pris DKK 500

ISBN 978-87-7749-715-5

Redaktørene har nå kommet med den fjerde utgaven av deres lærebok i miljø- og arbeidsmedisin. Den andre utgaven ble anmeldt i Tidsskriftet i $2003 \mathrm{og}$ anbefalt bl.a. også for kommunehelsetjenesten (1). Ved Det medisinske fakultet ved Norges teknisk-naturvitenskapelige universitet har vi brukt både den andre og den tredje utgaven som anbefalt litteratur for medisinstudentene. Vi var derfor spente da den lenge varslede fjerde utgaven nå endelig kom.

Litt av grunnen til at vi, ved siden av Leiras lille lærebok $i$ arbeidsmedisin (2), har anbefalt tidligere utgaver, er at den danske boken er systematisk med en grei kapitteloversikt over sentrale temaer som gjør at den også er lett å slå opp i. Det er også litt spesielt at forlaget aktivt bruker medisinstudenter som rådgivere i det redaksjonelle arbeidet, og at boken er fagfellevurdert. De fleste av de 23 kapitlene omhandler allmenngyldige faglige temaer. I denne utgaven, i så nær som ett kapittel, har man unngått å skjele til spesielle forhold eller regler som måtte gjelde i Danmark eller i EU. Det gjør denne utgaven enda bedre egnet som en generell lærebok. Det er også bra at det er korte innledninger i egne kapitler om risikovurdering og risikohåndtering, forebygging og i basisfaget toksikologi, mens epidemiologiske forhold, i den grad de er med, er dekket i kapitlene om de enkelte arbeidsrelaterte sykdomsgruppene. I hvert kapittel er det innarbeidet tekstbokser med korte og litt lengre kasuistikker (problembeskrivelser), og alle kapitlene avsluttes med en «test deg selv»-rubrikk og en kortfattet litteraturoversikt. Stikkordregisteret på slutten er ikke altfor omfattende, men oversiktlig og greit i forhold til innholdet.

Denne utgaven har med sine 353 sider blitt 58 sider tykkere enn den andre utgaven, som noen av oss nok syntes ble litt vel tynn i forhold til alt som bør dekkes. Alt i alt synes jeg at de tre redaktørene og deres 20 habile medforfattere har fătt til en lærebok i miljø- og arbeidsmedisin som jeg fortsatt gjerne anbefaler for våre medisinstudenter $\mathrm{og}$ andre med interesse for faget.

\section{Bjørn Hilt}

Professor II, Institutt for samfunnsmedisin

Norges teknisk-naturvitenskapelige universitet

\section{Litteratur}

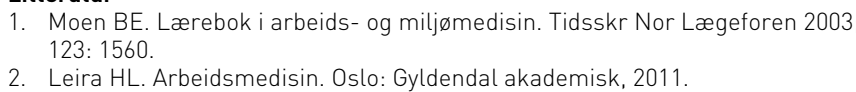

